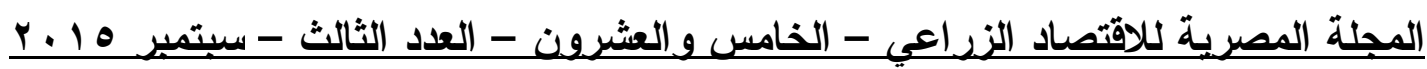

\title{
Data Envelopment Analysis for Wheat Production in Egypt
}

\author{
Yahia Hamid A. Elasraag \\ Lecturer, Department of Agricultural Economics, Faculty \\ of Agriculture, Cairo University, Giza, 12613, Egypt. \\ Attyat Mohamed E. Abou Zaid \\ Assistant Professor, Department of Agricultural Economics, \\ Faculty of Agriculture, Cairo University, Giza, 12613, Egypt.
}

\section{Abstract}

The study aim to measure the total factor productivity (TFP) of the main governorates of wheat production in Egypt during the time period 1990-2012 and decompose it into two components, technical change and efficiency change. We use Malmquist TFP index (DEA model). The results indicate that the mean of TFP change of the main governorates of wheat production in Egypt declined through the period of study, this decline is due mainly to the technical change than the efficiency change.

Keywords: total factor productivity, wheat, Malmquist index, Egypt

\section{Introduction}

Egypt occupies the north-east corner of Africa and lies between latitudes $22^{\circ} \mathrm{N}$ and $32^{\circ} \mathrm{N}$ and longitudes $25^{\circ} \mathrm{E}$ and $36^{\circ} \mathrm{E}$. Most of the country has a hot sub-tropical desert climate. Winters are without frost, but sufficiently cool for wheat. Rainfall is negligible. No crop can be grown in this climate without irrigation. The mean daily temperature during the wheat growing period range from $15.7^{\circ} \mathrm{C}$ to $21.4^{\circ} \mathrm{C}$. A narrow belt about $60 \mathrm{~km}$ wide along the entire northern coast has a sub-tropical semi-arid Mediterranean climate. Annual rainfall, in winter and spring, is between 100 and 200 $\mathrm{mm}$. The completely dry summers are warm, and the winters are without frost, but cool. In this coastal belt the marine influence holds the mean minimum temperature in winter above $12.0^{\circ} \mathrm{C}$. Precipitation is too small for even a marginal wheat crop. There is a low potential for rainfed barley. A narrow strip of land along the Red Sea coast in the south-eastern part of the country has a hot tropical desert climate. Rainfall is negligible and winters are too warm for wheat (FAO, 2011).

Wheat is a various species of the genus Triticum and it is a grass with so many important uses that it is cultivated worldwide. Wheat grain is a staple food used to make flour for leavened, flat and steamed breads, cookies, cakes, pasta, noodles and recently, biofuel. The husk of the grain, separated when milling white flour, is bran. Wheat germ is the embryo portion of the wheat kernel. It is a concentrated source of vitamins, minerals, and protein, and is sustained by the larger, starch storage region of the kernel. Some wheat is planted as a forage crop for livestock, straw made from stems and leaves can be used as bedding for livestock, or as a construction material for roofing thatch (Gowayed, 2009). In Egypt wheat is the most important winter crop grown. It is produced widely in both the older farming lands of the Delta and in the newly-farmed lands reclaimed from the desert. For over $97 \%$ of the total wheat crop, the soft varieties dominate domestic production. The exception to this is found in the southern governorates of Assuit, Menia, and Suhag, where some hard to extrahard types (durum) of wheat are grown (Tyner et al., 1999). Total planted area increased due mainly to an increase in government procurement prices, the increased profitability of wheat-based rotation, the implementation of more productive cultural practices, and more liberal policy environment, which allowed farmers to base their 
crop planting decisions on market forces and provided them with an incentive to adopt modern technology. All these factors reinforced each other in making investment in wheat production a more attractive and lucrative enterprise (USDA, 1997 and Kherallah et al., 2000). The vast majority of Egyptian wheat farms are small, irrigated, and owner-operated. Irrigation is almost universal in Egyptian agriculture, allowing the cultivation of summer and winter crops. In the Frontier, irrigation water comes from wells. Wheat plays an important role in farmers' crop rotations. The most common winter-summer rotations are wheat-rice, clover-cotton, wheat-maize, and clover-maize (Kherallah et al., 2000). Egypt has one of the largest per capita consumption levels of wheat in the world, and it is one of the world's largest importers of wheat. Two major factors are seriously increasing the rate of change in domestic wheat consumption; the rate of population growth and the rate of growth in wheat consumption per capita. These two factors are, consequently, affected by numerous other factors such as the adopted economic policies, income and its distribution among individuals, and the rate of change in prices (Tyner et al., 1999). The Government of Egypt (GOE) does continue to intervene in several markets, including the wheat market. At the same time policy makers try to look ahead to design new policies which aim to achieve greater food security. On the supply side, GOE policy is to achieve the highest possible self-sufficiency in wheat, basically to avoid international risks in wheat markets. Government procurement is typically at prices that are mostly higher than world equivalent prices. A further important contributing factor was raising yields after 1986 due to the diffusion of high-yielding long-spike varieties. Government intervention aimed at increasing selfsufficiency in wheat, thus reducing dependency on imports through support prices provided to wheat farmers and expansion of wheat area (Croppenstedt et al., 2006).

\section{Problem and Objective of the Study}

Wheat production in Egypt less than its consumption, and the population growth in Egypt have important implications on the Egyptian wheat economy, because the demand for wheat is still shifting to the right since wheat is considered as a strategic commodity in the country. The study of total factor productivity of wheat production in Egypt is very important indicator because it provides more precise information about what happen in the production process and it can help in increasing the wheat production. This study aims to measure the total factor productivity of the main governorates of wheat production in Egypt during the time period 1990-2012 and decompose it into technical change and efficiency change. The paper is organized as follows; the next section presents the literature review. Section 3 contains the methodology. Section 4 describes the data. Section 5 indicates the results, and the final section presents the conclusions.

\section{Literature Review}

The terms productivity and efficiency are often used interchangeably but they are not precisely the same things (Coelli and Rao, 2005). Productivity is an absolute concept and is measured by the ratio of outputs to inputs while efficiency is a relative concept and is measured by comparing the actual ratio of outputs to inputs with the optimal ratio of outputs to inputs (Javed, 2009). Agricultural productivity growth can be defined as agricultural outputs growth at a sufficiently rapid rate to meet the growth of demand for food and raw materials arising out of steady population growth (Kaliji et al., 2013). Researchers and policy makers are interested in measuring not only the levels and trends in agricultural productivity but also what sources are 
attributed to the agricultural productivity growth. In early studies of the measurement of productivity growth, a number of techniques were employed to construct productivity growth indices to measure the productivity growth. However, the indices have disadvantages because it requires data on prices and quantities as well as assumptions concerning the behavior of producers and the structure of technology. Moreover, it cannot provide what sources attributing to productivity growth which is of broad interest of researchers. These problems lead to the development of new empirical techniques known as non-parametric and parametric approaches to measure the productivity growth. The production frontier represents the maximum output attainable from each input level. Hence it reflects the current state of technology. Firms operate either on that frontier, if they are technologically efficient or beneath the frontier if they are not technically efficient (Covaci and Sojková, 2006). When we consider productivity comparisons through time, an additional source of productivity change, called technical change, is possible. When we observe that firm has increased its productivity from one year to the next, the improvement not from efficiency improvements alone, but may have occurred due to technological change or the exploitation of scale economies or from some combination of these three factors.

Many studies on productivity in the field of agricultural production have used Data Envelopment Analysis (DEA) approach, which was developed first and is popular for several reasons (Headey et al., 2010):

- DEA is a nonparametric technique that does not require a prior specific functional form for the production frontier.

- DEA is capable of handling multiple outputs and multiple inputs and does not require them to be aggregated.

- Because DEA is based on linear programming techniques, it is possible to identify the best practice for every firm.

- DEA provides information about the peers that can offer insights into how efficiency of the firm concerned can be improved.

- DEA provides a simple framework to measure efficiency change and technical change for each firm in the sample along with measures of TFP growth.

In recent years several studies have been conducted on the total factor productivity (TFP) based on DEA, which provides an indicator to compare productivity performance between firms and over time. Bushara and Barakat (2010) carried out a study to decompose total factor productivity change of cotton cultivars (Barakat-90 and Barac (67)B) in the Gezira scheme, Sudan during the time period 1991-2007 into two components technological change and technical efficiency change and the latter was further divided into scale efficiency change and pure efficiency change. The study based on the Data Envelopment Analysis Program using model of Malmquist indices. The output was the cotton cultivars while the inputs were land, water, capital, material, and labor. The results indicated that total factor productivity change was $-1.3 \%$ for the period 1991 to 2007 , the contribution of technical efficiency change was $-1.6 \%$ and technological change was $0.30 \%$, the main problem was the efficiency change and this was mainly due to scale inefficiency, Barac (67)B contributed to this negative at an average annual rate $3.3 \%$. This implying that Barac (67)B was ailing due to efficiency change. Korkmaz (2011) carried out a study to determine the total factor productivity changes between the years 2006 and 2010 at the state forest enterprises bound to Isparta regional forest directorate located at the Western Mediterranean region in Turkey. The Malmquist Productivity Index as a non-parametric approach was used in the study. Malmquist 
productivity index evaluated based on the data envelopment analysis. Input factors were the actual capital of forest enterprises, production costs, and amount of employees while the output factors were the total amount of production of logs, mine poles, and the value added. Technical efficiency change value had reached its highest level in 2007-2008 with an increase of $11.5 \%$. Technological change value had shown increase in the first and the last periods while ruled towards decrease during the other periods. Pure technical efficiency change value had reached its maximum level in 2007-2008 but then was subject to decrease in the following years. There was no change seen in the scale efficiency change values. For the total factor productivity changes values, besides the increase seen in the first period with a rate of $0.2 \%$, the following periods experienced decrease. The reason for the increase in such period was due to the contribution of the technological change values with a rate of $12.3 \%$. However, the technical efficiency change values of the period had disaffected the total factor productivity changes values with a rate of $10.7 \%$. Chaudhary (2012) conducted a study to estimate total factor productivity (TFP) in Indian agriculture at state-level for the years 1983-1984 to 2005-2006. Changes in TFP estimated by using the non-parametric Sequential Malmquist TFP index based on Data Envelopment Analysis. TFP change decomposed into efficiency change and technical change. The study used the index of agricultural production as the measure of output while the inputs were land, water, fertilizer, tractors, and livestock. The results indicated that productivity improvements were marked in very few states. The contribution of technical change is greater than that of efficiency change to overall productivity changes in all the states. The improvements in efficiency were observed to be low for most of the states and efficiency decline was observed in several states implying huge potential increase in production even with the existing technology. Hajian et al. (2013) carried out a study to measure the technical, allocative, and economic efficiency; and the total factor productivity for the strategic agronomy products including wheat, barley, rice, cotton and sugar beet during 1995 to 2009 by Malmquist index and Data Envelopment Analysis method. The output was the production of wheat, barley, rice, cotton and sugar beet while the inputs were seed, chemical fertilizer, antipest, labor and land. The results indicated that productivity for these products has generally risen in this period. Technical efficiencies were in high levels but allocative and economic efficiencies were in lower levels. Kaliji et al. (2013) conducted a study to gauge total factor productivity (TFP) of wheat production and its components which are technical efficiency and technological change in three Northern provinces, Iran. The study based on Malmquist index using DEA. The output was the production quantity of wheat while the inputs were land, seed, poison, fertilizer, labor, and machineries. The results showed that during the study period (2000-2011) TFP changes in Golestan Province was more effected by technological changes, while in Gilan and Mazandran the TFP was more affected by technical efficiency. Changes in TFP for the whole country showed large fluctuations. These changes were due to changes in technical efficiency and technological change.

We did not find empirical works that estimate the total factor productivity (TFP) of wheat production on the level of governorates in Egypt. Therefore, from this perspective this is a novel work. From the point of view of establishing an agricultural policy for Egypt, the contributions of this work are important because it provides recommendations for improvement. 


\section{Methodology}

The parametric and nonparametric approaches are extensively applied to measure TFP growth. The parametric approach uses a production function, while the nonparametric approach uses a linear programming method, in this method Malmquist index is defined using distance function.

A more generally used index for measuring growth in total factor productivity is Tornqvist index. Tornqvist productivity index assumes a translog production function and gives exact results for the translog specification. Since the translog form is flexible Diewert (1976), regards the Tornqvist index as a superlative means of determining productivity growth (Färe et al. 1994). Since Tornqvist index assumes efficient production, it has the drawback of not differentiating productivity growth into the two possible components of change in performance and change in technology. Malmquist index, on the contrary, does not require any assumptions regarding efficiency and functional form, and is therefore able to distinguish between the factors causing changes in productivity. According to Coelli (1996); Malmquist TFP index (DEA model) may be used to measure productivity change and to decompose the productivity change into technical change and technical efficiency in the presence of panel data.

The Malmquist TFP index was introduced as a theoretical index by Caves et al. (1982) and popularized as an empirical index by Färe et al. (1994). They defined the TFP index using Malmquist input and output distance functions, and thus the resulting index came to be known as the Malmquist TFP index (Chaudhary, 2012). The Malmquist TFP change index between period $t$ (the base period) and period $t+1$ is given by equation (1):

$$
M^{t}=\frac{D_{o}^{t}\left(x^{t+1}, y^{t+1}\right)}{D_{o}^{t}\left(x^{t}, y^{t}\right)}
$$

where, $D_{o}^{t}\left(x^{t+1}, y^{t+1}\right)$ is the output distance function at the observed input vector $\mathrm{x}$ and the observed output vector y. $D_{o}^{t}\left(x^{t+1}, y^{t+1}\right)$ represents the distance from the period $t+1$ observation to the period $t$ technology.

i.e., they define the productivity index as the ratio of two output distance functions taking technology at time $t$ as the reference technology. Instead of using period $t$ 's technology as the reference technology it is possible to construct output distance functions based on period $(t+1)$ 's technology and thus another Malmquist productivity index can be laid down as equation (2):

$$
M^{t+1}=\frac{D_{o}^{t+1}\left(x^{t+1}, y^{t+1}\right)}{D_{o}^{t+1}\left(x^{t}, y^{t}\right)}
$$

Färe et al (1994) specify Malmquist productivity change index as the geometric mean of two-period indices that is (3):

$$
M_{o}\left(x^{t+1}, y^{t+1}, x^{t}, y^{t}\right)=\left[\left(\frac{D_{o}^{t}\left(x^{t+1}, y^{t+1}\right)}{D_{o}^{t}\left(x^{t}, y^{t}\right)}\right)\left(\frac{D_{o}^{t+1}\left(x^{t+1}, y^{t+1}\right)}{D_{o}^{t+1}\left(x^{t}, y^{t}\right)}\right)\right]^{1 / 2}
$$

The equation (3) can be written as the product of two distinct components, technical change and efficiency change (Färe et al. 1994), as it is shown in equation (4):

$$
M_{o}\left(x^{t+1}, y^{t+1}, x^{t}, y^{t}\right)=\frac{D_{o}^{t+1}\left(x^{t+1}, y^{t+1}\right)}{D_{o}^{t}\left(x^{t}, y^{t}\right)}\left[\left(\frac{D_{o}^{t}\left(x^{t+1}, y^{t+1}\right)}{D_{o}^{t+1}\left(x^{t+1}, y^{t+1}\right)}\right)\left(\frac{D_{o}^{t}\left(x^{t}, y^{t}\right)}{D_{o}^{t+1}\left(x^{t}, y^{t}\right)}\right)\right]^{1 / 2}
$$


where,

Efficiency change $=\frac{D_{o}^{t+1}\left(x^{t+1}, y^{t+1}\right)}{D_{o}^{t}\left(x^{t}, y^{t}\right)}$

Technical change $=\left[\left(\frac{D_{o}^{t}\left(x^{t+1}, y^{t+1}\right)}{D_{o}^{t+1}\left(x^{t+1}, y^{t+1}\right)}\right)\left(\frac{D_{o}^{t}\left(x^{t}, y^{t}\right)}{D_{o}^{t+1}\left(x^{t}, y^{t}\right)}\right)\right]^{1 / 2}$

Hence the Malmquist productivity index is simply the product of the change in relative efficiency that occurred between periods $t$ and $t+1$, and the change in technology that occurred between periods $t$ and $t+1$. A value of Malmquist TFP index equal to one implies there has been no change in total factor productivity across the two time periods, greater than one implies a growth in TFP and a value less than one is interpreted as deterioration in TFP. A similar interpretation applies to the two components as well.

The value of efficiency change measures the overall change in relative efficiency, and is a measure of the distance between observed production and the maximum possible production level between the two time periods $t$ and $t+1$. The component of technical change, calculated as the geometric mean of two ratios, measures the shift in production technology. This ratio represents the relative change in the input technologies over the time period $t$ and $t+1$ (i.e. change in $x^{t}$ and $x^{t+1}$ ).

Färe et al. (1994) decomposed the efficiency change into pure efficiency change and scale efficiency change (this can only be done when the distance functions are estimated relative to constant returns to scale (CRS) technology).

Pure efficiency change $=\frac{D_{o v}^{t+1}\left(x^{t+1}, y^{t+1}\right)}{D_{o v}^{t}\left(x^{t}, y^{t}\right)}$

Scale efficiency change $=\left[\frac{D_{o v}^{t+1}\left(x^{t+1}, y^{t+1}\right) / D_{o c}^{t+1}\left(x^{t+1}, y^{t+1}\right)}{D_{o v}^{t+1}\left(x^{t}, y^{t}\right) / D_{o c}^{t+1}\left(x^{t}, y^{t}\right)} \times \frac{D_{o v}^{t}\left(x^{t+1}, y^{t+1}\right) / D_{o c}^{t}\left(x^{t+1}, y^{t+1}\right)}{D_{o v}^{t}\left(x^{t}, y^{t}\right) / D_{o c}^{t}\left(x^{t}, y^{t}\right)}\right]^{1 / 2}$

The scale efficiency change is actually the geometric mean of two scale efficiency change measures. The first is relative to the period $t+1$ technology and the second is relative to the period $t$ technology. The extra subscripts, $v$ and $c$, relate to the variable returns to scale (VRS) and CRS technologies, respectively.

\section{Data}

The data that employed for this study are obtained from the Ministry of Agriculture and Land Reclamation (MALR), Egypt. The panel data composed of eleven governorates represents the main governorates of wheat production in Egypt during the time period 1990-2012. To measure the total factor productivity of the main governorates of wheat production in Egypt between period $t$ and period $t+1$ as reported in equation (4) and decompose it into its components, we apply the Malmquist TFP index as a non-parametric approach. To estimate the Malmquist TFP index we use DEA program version 2.1 of Coelli (1996). The summary statistics for the variables used in the analysis are presented in Table 1. The production inputs comprise three input variables (land, labor and machinery) while there is only one output (wheat production). Wheat production has been estimated in thousand tons and land has been estimated in thousand hectares. Labor and machinery have been estimated in thousand hours.

\section{Results}

Table 2 shows a decomposition of Malmquist Index (TFPCH) for wheat production in Egypt during the time period 1990-2012 into two components, 
technical change (TECHCH) and efficiency change (EFFCH). Furthermore, efficiency change decomposes into pure efficiency change (PECH) and scale efficiency change (SECH).

Malmquist Indices by year are presented in Table 2. The mean of TFPCH of wheat production in Egypt during the time period 1990-2012 has a value less than one and shows a decline; this decline is generally improves over time. This result is due mainly to the behavior of technical change component than the efficiency change component. The period 2009-2010 has the less declining in TFPCH by $0.3 \%$, while the period 1990-1991 has the more declining in TFPCH by $38.9 \%$.

Table 1. Summary statistics for the variables (1990-2012).

\begin{tabular}{|c|c|c|c|c|c|}
\hline Variables & Units & Maximum & Minimum & Mean & Std. Dev. \\
\hline Output $\left(y_{i t}\right)$ & Tons (thousands) & 1144.62 & 195.00 & 474.46 & 192.47 \\
\hline Land $\left(\mathrm{x}_{1 i t}\right)$ & Hectares (thousands) & 178.52 & 20.92 & 74.46 & 29.22 \\
\hline Labor $\left(\mathrm{x}_{2 i t}\right)$ & Hours (thousands) & 110466.20 & 13191.72 & 46973.43 & 18421.22 \\
\hline Machinery $\left(\mathrm{x}_{3 i t}\right)$ & Hours (thousands) & 12321.23 & 1045.38 & 4325.39 & 1799.44 \\
\hline
\end{tabular}

Source : Own elaboration from the sample data (Ministry of Agriculture and Land Reclamation, Egypt)

Table 2. Malmquist Indices by year ${ }^{\mathrm{a}}$.

\begin{tabular}{|c|c|c|c|c|c|}
\hline & \multicolumn{3}{|c|}{ Decomposition of Efficiency Change } & \\
\hline Period & $\begin{array}{c}\text { Technical } \\
\text { Change } \\
\text { (TECHCH) }\end{array}$ & $\begin{array}{c}\text { Efficiency } \\
\text { Change } \\
\text { (EFFCH) }\end{array}$ & $\begin{array}{c}\text { Pure Efficiency } \\
\text { Change } \\
\text { (PECH) }\end{array}$ & $\begin{array}{c}\text { Scale Efficiency } \\
\text { Change } \\
\text { (SECH) }\end{array}$ & $\begin{array}{c}\text { Malmquist } \\
\text { Index } \\
\text { (TFPCH) }\end{array}$ \\
\hline $\mathbf{1 9 9 0 - 1 9 9 1}$ & 0.613 & 0.997 & 0.997 & 1.000 & 0.611 \\
\hline $\mathbf{1 9 9 1 - 1 9 9 2}$ & 0.733 & 1.016 & 1.017 & 0.999 & 0.745 \\
\hline $\mathbf{1 9 9 2 - 1 9 9 3}$ & 0.821 & 0.987 & 0.986 & 1.001 & 0.810 \\
\hline $\mathbf{1 9 9 3 - 1 9 9 4}$ & 0.839 & 0.991 & 0.991 & 1.000 & 0.831 \\
\hline $\mathbf{1 9 9 4 - 1 9 9 5}$ & 0.832 & 1.004 & 1.004 & 1.000 & 0.835 \\
\hline $\mathbf{1 9 9 5 - 1 9 9 6}$ & 0.879 & 1.000 & 1.000 & 1.000 & 0.879 \\
\hline $\mathbf{1 9 9 6 - 1 9 9 7}$ & 0.892 & 0.997 & 0.997 & 1.000 & 0.889 \\
\hline $\mathbf{1 9 9 7 - 1 9 9 8}$ & 0.898 & 1.007 & 1.007 & 1.000 & 0.904 \\
\hline $\mathbf{1 9 9 8 - 1 9 9 9}$ & 0.920 & 0.992 & 0.992 & 1.000 & 0.913 \\
\hline $\mathbf{1 9 9 9 - 2 0 0 0}$ & 0.914 & 1.003 & 1.003 & 1.000 & 0.917 \\
\hline $\mathbf{2 0 0 0 - 2 0 0 1}$ & 0.942 & 0.991 & 0.991 & 1.000 & 0.934 \\
\hline $\mathbf{2 0 0 1 - 2 0 0 2}$ & 0.925 & 1.006 & 1.006 & 1.000 & 0.931 \\
\hline $\mathbf{2 0 0 2 - 2 0 0 3}$ & 0.930 & 0.997 & 0.997 & 1.000 & 0.927 \\
\hline $\mathbf{2 0 0 3 - 2 0 0 4}$ & 0.942 & 1.001 & 1.001 & 1.000 & 0.943 \\
\hline $\mathbf{2 0 0 4 - 2 0 0 5}$ & 0.928 & 1.004 & 1.004 & 1.000 & 0.932 \\
\hline $\mathbf{2 0 0 5 - 2 0 0 6}$ & 0.947 & 1.004 & 1.004 & 1.000 & 0.951 \\
\hline $\mathbf{2 0 0 6 - 2 0 0 7}$ & 0.969 & 0.998 & 0.998 & 1.000 & 0.967 \\
\hline $\mathbf{2 0 0 7 - 2 0 0 8}$ & 0.933 & 1.003 & 1.003 & 1.000 & 0.936 \\
\hline $\mathbf{2 0 0 8 - 2 0 0 9}$ & 0.942 & 1.005 & 1.005 & 1.000 & 0.947 \\
\hline $\mathbf{2 0 0 9 - 2 0 1 0}$ & 0.999 & 0.998 & 0.998 & 1.000 & 0.997 \\
\hline $\mathbf{2 0 1 0 - 2 0 1 1}$ & 0.943 & 0.997 & 0.997 & 1.000 & 0.940 \\
\hline $\mathbf{2 0 1 1 - 2 0 1 2}$ & 0.947 & 1.011 & 1.011 & 1.000 & 0.957 \\
\hline Mean & 0.895 & 1.000 & 1.000 & 1.000 & 0.895 \\
\hline
\end{tabular}

$\left({ }^{a}\right)$ Geometric mean (1990-2012)

Source : Own elaboration

Table 3 shows a decomposition of Malmquist Index (TFPCH) of the main governorates of wheat production in Egypt during the time period 1990-2012 into two components, technical change (TECHCH) and efficiency change $(\mathrm{EFFCH})$. Furthermore, efficiency change decomposes into pure efficiency change $(\mathrm{PECH})$ and scale efficiency change (SECH). 
Table 3. Malmquist Indices by governorate ${ }^{\text {a }}$.

\begin{tabular}{|c|c|c|c|c|c|}
\hline & & \multicolumn{3}{|l|}{ Decomposition of Efficiency Change } \\
\hline Governorate & $\begin{array}{c}\text { Technical } \\
\text { Change } \\
\text { (TECHCH) }\end{array}$ & $\begin{array}{c}\text { Efficiency } \\
\text { Change } \\
\text { (EFFCH) }\end{array}$ & $\begin{array}{c}\text { Pure Efficiency } \\
\text { Change } \\
\text { (PECH) }\end{array}$ & $\begin{array}{c}\text { Scale Efficiency } \\
\text { Change } \\
\text { (SECH) }\end{array}$ & $\begin{array}{c}\text { Malmquist } \\
\text { Index } \\
\text { (TFPCH) }\end{array}$ \\
\hline Sharkia & 0.869 & 1.000 & 1.000 & 1.000 & 0.869 \\
\hline Dakahlia & 0.869 & 1.000 & 1.000 & 1.000 & 0.869 \\
\hline Behairah & 0.871 & 1.000 & 1.000 & 1.000 & 0.871 \\
\hline Menia & 0.887 & 1.000 & 1.000 & 1.000 & 0.887 \\
\hline Fayoum & 0.891 & 0.999 & 0.999 & 1.000 & 0.890 \\
\hline Assuit & 0.894 & 1.000 & 1.000 & 1.000 & 0.894 \\
\hline Suhag & 0.887 & 1.001 & 1.001 & 1.000 & 0.888 \\
\hline Gharbia & 0.897 & 1.001 & 1.001 & 1.000 & 0.898 \\
\hline Beni Suef & 0.919 & 1.005 & 1.005 & 1.000 & 0.924 \\
\hline Menoufia & 0.935 & 1.000 & 1.000 & 1.000 & 0.935 \\
\hline Kafr Elshikh & 0.879 & 1.000 & 1.000 & 1.000 & 0.879 \\
\hline Mean $^{\mathbf{a}}$ & 0.891 & 1.001 & 1.001 & 1.000 & 0.891 \\
\hline
\end{tabular}

$\left.{ }^{\mathrm{a}}\right)$ Geometric mean (1990-2012)

Source: Own elaboration

Malmquist Indices by governorate are presented in Table 3. The results indicate that the mean of TFPCH of the main governorates of wheat production in Egypt declined by $10.9 \%$. The mean of declining in the component of technical change is $10.9 \%$, this decline is generally improves over time. The mean of increasing in the component of efficiency change is $0.1 \%$, the source of this increasing is mainly due to the component of pure efficiency change than the component of scale efficiency change, as the mean of scale efficiency change is equal to one. Therefore, the decline in the TFPCH is due more to the technical change than the efficiency change. The less declining in TFPCH occurred at Menoufia governorate by $6.5 \%$, while the more declining in TFPCH occurred at two governorates, Sharkia and Dakahlia by $13.1 \%$ for each of them.

\section{Conclusions}

Wheat is one of the most important agricultural crops in Egypt. The study is intended to measure the wheat productivity change by examining the production technology and efficiency of this crop over the time period 1990-2012. We use Malmquist TFP index as a non-parametric approach (DEA) to decompose total factor productivity of the main governorates of wheat production in Egypt into technical change and efficiency change. The data of this study are obtained from the Ministry of Agriculture and Land Reclamation, Egypt. The TFPCH of wheat production in Egypt during the time period 1990-2012 has a value less than one and shows a decline; this decline is due mainly to the technical change component than the efficiency change component. The decline in TFPCH is generally improves over time. Menoufia governorate has the less declining in TFPCH by $6.5 \%$, while two governorates, Sharkia and Dakahlia have the more declining in TFPCH by $13.1 \%$ for each of them. The less declining in TFPCH occurred at the period 2009-2010 by $0.3 \%$, while the more declining in TFPCH occurred at the period 1990-1991 by $38.9 \%$. The declining in TFP of wheat production in Egypt is attributed mainly to poor application of technology.

\section{Recommendations}

From this study we suggest the following recommendations, increase the area of wheat production through the reclaimed agricultural areas; improve and increase the technology level of wheat production; increase the effects of scale by the implementing of land consolidation system to increase the scale efficiency and reduce the costs; improve the training of labor, especially the skills of cultivation and harvesting of wheat; and increase the research with the purpose of taking advantage 
of genetic improvements, which should enable the introduction of new wheat varieties with higher productivity. There is a need for more studies on TFP of wheat production in Egypt. Future works need to carry out these studies on the farm level through the use of surveys.

\section{References}

- Bushara, M.O.A., and Barakat, H.E. (2010). Decomposing Total Factor Productivity Change of Cotton Cultivars (Barakat-90 and Barac (67) B) in the Gezira Scheme (1991-2007) Sudan. Contributed Paper presented at the Joint $3^{\text {rd }}$ African Association of Agricultural Economists and $48^{\text {th }}$ Agricultural Economists Association of South Africa Conference, Cape Town, South Africa, September 19-23.

- Caves, D.W., Christensen, L.R., Laurits, R., and Diewert, W.E. (1982). The economic theory of index numbers and the measurement of input, output, and productivity. Econometrica 50: 1393-1414.

- Chaudhary, S. (2012). Trends in Total Factor Productivity in Indian Agriculture: State-level Evidence Using Non-Parametric Sequential Malmquist Index. Centre for Development Economics, Department of Economics, Delhi School of Economics, Working Paper No. 215.

- Coelli, T.J. (1996). A guide to DEAP Version 2.1: A Data Envelopment Analysis (Computer) Program. Centre for Efficiency and Productivity Analysis (CEPA), CEPA Working Paper, No. 8/96, Department of Econometrics, University of New England, Armidale, Australia.

- Coelli, T.J. (1996). Measurement of total factor productivity and biases in technological change in Western Australian agriculture. Journal of Applied Econometrics 11: 77-91.

- Coelli, T.J., and Perelman, S. (2000). Technical efficiency of European railways: A distance function approach. Appl. Econ. 32: 1967-1976.

- Coelli, T.J., Prasada Rao, D.S., O'Donnell, C.J., and Battese, G.E. (1998). An Introduction to Efficiency and Productivity Analysis. Springer, Second Edition, ISBN-10: 0-387-24265-1.

- Coelli, T.J., and Rao, D.S.P. (2005). Total factor productivity growth in agriculture: A Malmquist Index analysis of 93 countries 1980-2000. Agric. Econ. 32: 115-134.

- Constantin, P.D., Martin, D.L., and Rivera, E.B.B.R. (2009). Cobb-Douglas, translog stochastic production function and data envelopment analysis in total factor productivity in Brazilian agribusiness. Journal of Operations and Supply Chain Management 2 (2): 20-34.

- Covaci, S., and Sojková, Z. (2006). Investigation of wheat efficiency and productivity development in Slovakia. Agric. Econ.-Czech 52 (8): 368-378.

- Diewert, W.E. (1976). Exact and superlative index numbers. Journal of Econometrics 4: 115-145.

- Dolisca, F., and Jolly, C.M. (2008). Technical efficiency of traditional and nontraditional crop production: A case study from Haiti. World Journal of Agricultural Sciences 4 (4): 416-426.

- Färe, R., Grosskopf, S., Norris, M., and Zhang, Z. (1994). Productivity growth, technical progress, and efficiency change in industrialized countries. American Economic Review 84: 66-83.

- Hajian, M., Sadeghi, H., and Javaheri, B. (2013). Total factor productivity and efficiency in Iranian crop production: A none parametric approach. Research Journal of Agricultural and Environmental Management 2 (2): 033-043. 
- Headey, D., Alauddin, M., and Rao, D.S.P. (2010). Explaining agricultural productivity growth: An international perspective. Agricultural Economics 41: 1-14.

- Hossain, M.K., Kamil, A.A., Baten, M.A., and Mustafa, A. (2012). Stochastic frontier approach and data envelopment analysis to total factor productivity and efficiency measurement of Bangladeshi rice. PLOS ONE 7 (10), e46081.

- Javed, M.I. (2009). Efficiency Analysis of Cotton-Wheat and Rice-Wheat Systems in Punjab, Pakistan. Doctoral Thesis. Faculty of Agricultural Economics and Rural Sociology, University of Agriculture, Faisalabad.

- Jin, S., Ma, H., Huang, J., Hu, R., and Rozelle, S. (2010). Productivity, efficiency and technical change: Measuring the performance of China's transforming agriculture. $J$ Prod Anal 33:191-207.

- Kaliji, S.A., Bidabadi, F.S., and Aminravan, M. (2013). Total factor productivity of wheat technical changes or technical efficiency; case study of three northern provinces of Iran. International Journal of Agriculture and Crop Sciences 5 (4): 395-400.

- Korkmaz, M. (2011). Productivity changes of forest enterprises in Turkey: A nonparametric Malmquist approach. African Journal of Agricultural Research 6 (28): 6189-6196.

- Mahmood, A., and Afza, T. (2008). Total factor productivity growth in East Asia: A two pronged approach. European Journal of Economics, Finance and Administrative Sciences ISSN 1450-2275, Issue 14.

- MALR (1990-2012). Agricultural Statistics. Economic Affairs Sector, Ministry of Agriculture and Land Reclamation, Egypt.

- Squires, D., and Reid, C. (2004). Using Malmquist Indices to Measure Changes in Total Factor Productivity of Purse-Seine Vessels While Accounting for Changes in Capacity Utilisation, the Resource Stock and the Environment. Forum Fisheries Agency, Honiara, Solomon Islands. NOAA Fisheries, La Jolla, California, USA. SCTB17 Working Paper, FTWG-5. $17^{\text {th }}$ Meeting of the Standing Committee on Tuna and Billfish.

\section{الملخص}

القمح من المحاصيلِ الزر اعيةِ الهامة في مصر و إنتاج القمح في مصر أقل مين إستهلاكهِ مما يمثل

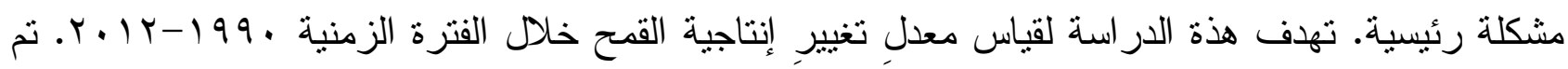

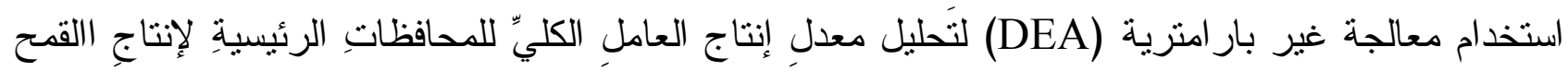

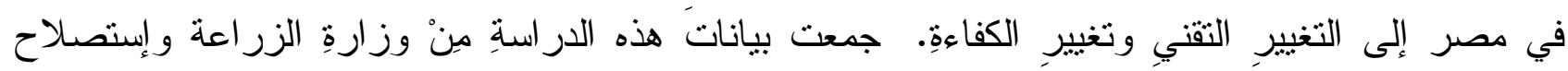

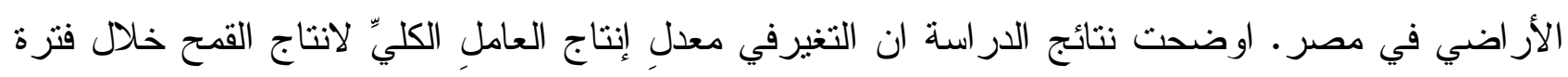

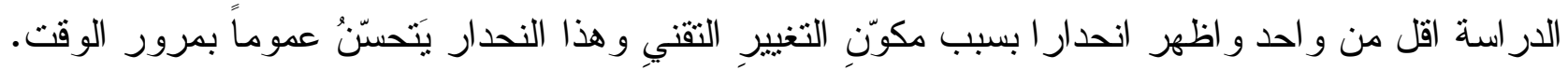

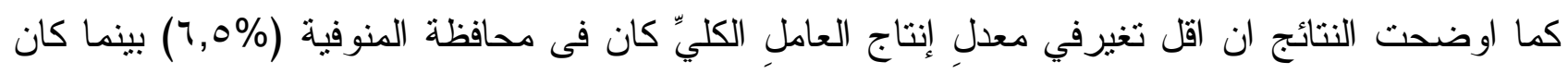

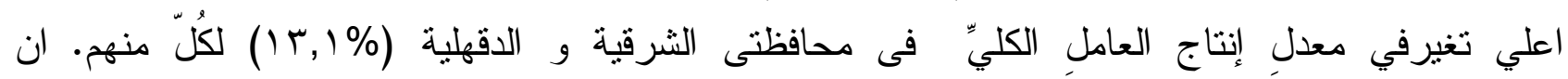

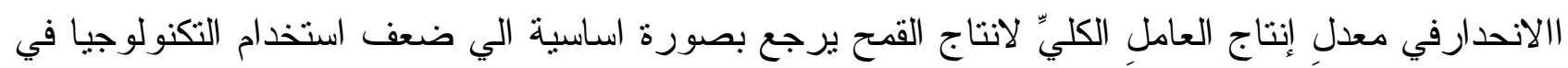

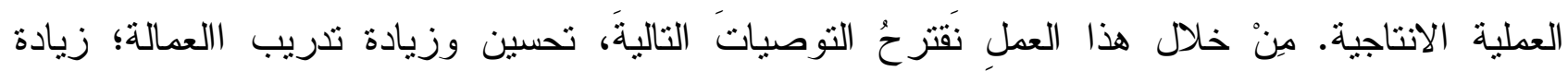

التكنولوجيا في عملية انتاج القمح واستخدام الاصناف ذات الانتاجية العالية. 